\title{
Economic Analysis of the Impact of Changing Production Conditions on Wheat Productivity Level
}

\author{
Kussainov, T. A. ${ }^{1}$, Mansoor Maitah ${ }^{2}$, Kurmanov, N. A. ${ }^{3}$, Petr Hájek ${ }^{4}$, Tolysbaev, B. S. ${ }^{3}$ \& Baidakov, A. K. ${ }^{1}$ \\ ${ }^{1}$ Department of Accounting and Audit, Faculty of Economics, S. Seifullin Kazakh Agrotechnical University, \\ Astana, Kazakhstan \\ ${ }^{2}$ Department of Economics, Faculty of Economics and Management, Czech University of Life Sciences Prague, \\ Prague 6, Czech Republic \\ ${ }^{3}$ Department of Management, Faculty of Economics, L.N. Gumilyov Eurasian National University, Astana, \\ Kazakhstan \\ ${ }^{4}$ Department of Economics and Management, Unicorn College s.r.o., Prague, Czech Republic
}

Correspondence: Mansoor Maitah, Department of Economics, Faculty of Economics and Management, Czech University of Life Sciences Prague, Kamycka 129, Prague 6 16921, Czech Rep. E-mail: maitah@pef.czu.cz

Received: March 17, 2015 Accepted: April 23, $2015 \quad$ Online Published: June 26, 2015

doi:10.5539/res.v7n11p125 URL: http://dx.doi.org/10.5539/res.v7n11p125

\begin{abstract}
Production conditions of crop growth have a considerable effect on the labour productivity rate because of the changes in the level of yield performance. In this paper the calculations have been made to estimate the correlation between production, including hydrothermal and grain yield indices in the Zelinogradsky district of the Akmolinskaya oblast (province) of Kazakhstan. As a result of estimation process, only the most significant factors have been included in the econometric model. A considerable inconsistency has been discovered in the correlation dependence between grain productivity and hydrothermal indices during a period of the years before the 1990s and afterward (due to the changes in economic and climatic conditions, as well as in the use of production technologies). The numerical parameters of the above-mentioned model were calculated on the experimental site of the agricultural enterprise "Rodina" LLP located in Zelingradsky district of the Akmolinskaya oblast.
\end{abstract}

Keywords: wheat, productivity, production factors, technology, weather conditions, model, Kazakhstan

\section{Introduction}

The mass production of wheat in Kazakhstan, when it was still part of the USSR, began in 1954 along with the launching of a plowing campaign of virgin and fallow lands. Within six years of the campaign (1954-1960), 25.5 million hectares of harvested area, or $61 \%$ of all plowed virgin and fallow lands across the former USSR was brought into operation (Lioubimtseva \& Henebry, 2012).

The historical maximum of total wheat yields was observed in 1956 at 19.2 million tons. By 1999 the wheat area declined by more than half to almost 9 million ha. Besides other factors related to the state of the economy and agriculture, the sharp decline was caused by weather conditions (Tarrant, 1984) and use of specific wheat production technologies (Longmire \& Moldashev, 1999). However, beginning in 2000, the wheat areas began to steadily increase and reached 13.1 million ha in 2012. Thus, the goal of the paper is to examine the impact of changing production conditions (specifically weather conditions and production practices) on wheat productivity level.

Similar studies and calculation methods of the impact of production conditions on wheat productivity level were carried out in the following works (Nagy \& Sanders, 1990; Morgounov et al., 2005). Different studies have assessed impacts of climate change on wheat productivity. Knight et al. (1978) analyzed the potential for wheat production in various regions of Alaska on the basis of air temperature. Ashfaq et al. (2011) studied that the climate change is the major determinant of wheat productivity at each stage of wheat growth. The majority of the existing methods are dedicated to labour productivity calculation as such and to its dynamics. At present the following researchers are studying the impact of production practices on labour productivity in Kazakhstan and throughout the Central Asian states (Shegebaev, 1997; Baydildina et al., 2000; Meng, 2000; Morgounov et al., 2007). 
Peer-reviewed journals have a small number of publications that touch upon the research question one way or the other; it is necessary to point out first of all the following works (Griffith et al., 1995; De Beurs \& Henebry, 2004).

\section{Method}

\subsection{The Problem Features}

To carry out our research on the measurement of the impact of production factors, including wheat growth technologies, the agricultural enterprise "Rodina" LLP was selected as the most appropriate site since it has a relatively more reliable and fuller database. The significant feature of the research problem is also its main difficulty. This is virtual impossibility of performing an experiment, whose primary aim is to compare and assess the efficiency of different agricultural technologies, under current socio-economic conditions. Furthermore, it is difficult to find enterprises with comparable conditions, that is, an enterprise where, for example, only an intensive technology is used or simplified, or a resource-saving technology is used. Therefore, the only possible way to solve this problem is to conduct a comparative analysis within the frames of an individual enterprise, with reference to retrospective historical data covering a considerable period of time, including the 1960s-70s (the time when conservation tillage technology was used), the 1980s (intensive technology), the 1990s-the beginning of the 2000s (simplified technology), and the early 2000s and up to the present (resource-saving technology). The crucial factors which affect wheat productivity level are considered to be weather hydrothermal production conditions. The calculation of the change in wheat productivity level given the use of a new technology is based on an econometric model.

\subsection{Evaluation and Concretization of Factors to Be Involved in the Model}

The selection of weather conditions periods to be involved in the model: Five precipitation periods were used for comparison in this model: Octobe-April; May-July; October-July; May-August; October-August. Average precipitation according to different technology application periods are presented in Table 1.

Table 1. Average precipitation according to different technology application periods, 1971-2012

\begin{tabular}{lllll}
\hline Indicator & & \multicolumn{2}{c}{ Technologies application period } \\
& $\begin{array}{l}\text { Conservation tillage } \\
\text { technology }\end{array}$ & $\begin{array}{l}\text { Intensive } \\
\text { technology }\end{array}$ & $\begin{array}{l}\text { Simplified } \\
\text { technology }\end{array}$ & Minimal technology \\
\hline $\begin{array}{l}\text { Average precipitation } \\
\text { October-July (mm) }\end{array}$ & 254.2 & 259.9 & 266.1 & 269.0 \\
$\begin{array}{l}\text { Average temperature } \\
\text { in June }\left(\mathrm{C}^{\circ}\right)\end{array}$ & 18.9 & 19.8 & 18.9 & 20.0 \\
\hline
\end{tabular}

a) Data from Zelinogradsky district at large:

\begin{tabular}{|c|c|c|c|c|c|c|c|}
\hline \multirow[t]{2}{*}{ Years } & \multicolumn{5}{|l|}{ Precipitation } & \multirow{2}{*}{$\begin{array}{l}\text { Temperature } \\
\text { in June }\end{array}$} & \multirow{2}{*}{$\begin{array}{l}\text { Temperature } \\
\text { in July }\end{array}$} \\
\hline & October-April & May-July & October-July & May-August & October-August & & \\
\hline 1971-1991 & 0.65 & 0.66 & 0.75 & 0.56 & 0.69 & -0.38 & -0.38 \\
\hline 1992-2012 & 0.03 & 0.47 & 0.37 & 0.39 & 0.33 & -0.75 & -0.29 \\
\hline $1971-2012$ & 0.31 & 0.51 & 0.55 & 0.43 & 0.51 & -0.55 & -0.29 \\
\hline
\end{tabular}

b) Data from agricultural enterprise "Rodina" LLP:

\begin{tabular}{|c|c|c|c|c|c|c|c|}
\hline \multirow[t]{2}{*}{ Years } & \multicolumn{5}{|l|}{ Precipitation } & \multirow{2}{*}{$\begin{array}{l}\text { Temperature } \\
\text { in June }\end{array}$} & \multirow{2}{*}{$\begin{array}{l}\text { Temperature } \\
\text { in July }\end{array}$} \\
\hline & October-April & May-July & October-July & May-August & October-August & & \\
\hline 1971-1991 & 0.62 & 0.47 & 0.60 & 0.37 & 0.54 & -0.40 & -0.05 \\
\hline $1992-2012$ & 0.09 & 0.60 & 0.46 & 0.44 & 0.37 & -0.63 & -0.28 \\
\hline $1971-2012$ & 0.30 & 0.55 & 0.53 & 0.42 & 0.46 & -0.49 & -0.21 \\
\hline
\end{tabular}


The structural analysis of hydrothermal conditions for 1971-2012 shows that there are considerable differences in the correlation between grain productivity and hydrothermal indicators during the period before and after the 1990s (due to the changes in economic and climatic conditions, as well as in production technologies application):

The above-mentioned circumstances require improvement of analytical methods and econometric model calibration, which seeks to establish a correlation between production results and economic production conditions.As can be seen from Table 1, the highest correlation is observed between wheat productivity level and the amount of precipitation during the period from October to July, and in May-July (according to data on Zelinogradsky district at large as well as according to an individual enterprise). Given that the wheat productivity level is affected by both the accumulated moisture and precipitation amount in the vegetation period, we had to include in the econometric model the amount of precipitation for the period from October to July as one of the factors. The correlation between wheat productivity and temperature regimes was evaluated according to different vegetation months. In this case, the closest correlation (and feedback correlation) is observed in the "wheat productivity - temperature in June" pair, both on the enterprise level and across the district at large. It follows that average air temperature in June needs to be included in the model as a temperature factor. The choice of the selected above variables is consistent with the conclusions of agronomists (Alstone et al., 1995; Longmire and Moldashev, 1999; Morgounov et al., 2001): 1) the critically sensitive period for spring wheat is related to the soil humidity level. This period is the stage of tillering and heading, when the reproductive organs form. If there is not a sufficient amount of moisture in the soil at this stage, the potential seed productivity sharply decreases. Given the conditions in Akmolinskaya oblast, this stage occurs in July; 2) the crucial stage of wheat formation is the tillering stage, which depends on temperature (Mizina et al., 1999; Babu \& Tashmatov, 2000; Morgounov et al., 2007; Liefert et al., 2010). High temperature at this time sharply reduces the wheat productivity level. This stage takes place in June.

\subsection{Evaluation of Other Factors to Be Included in the Model}

The application of fertilizers, including minerals, plays a significant role in increasing wheat productivity, as well as labour productivity. This study did not determine the correlation between crop productivity and the amount of fertilizers used.

In additional to factors that can be evaluated quantitatively, our study considered the importance of qualitative parameters: wheat varieties used, agricultural technologies, machinery and equipment. These qualitative parameters can be included in the model in the form of so called categorical variables which take value 1, if used, and 0 if they are not used in wheat production in the enterprise under investigation during certain periods of time. In the given research, periods of use of certain groups of wheat varieties almost perfectly match the transition periods from one technology to another.

During the 70s, the wheat varieties: "Saratovskaya" and "Zelinnaya" were used; during this time conservation tillage technology of wheat production was common. During the $80 \mathrm{~s}$, a time of intensive technology, the following wheat varieties were used: "Saratovskaya", "Zelinnaya", "Yubileynaya" and "Omskaya". During the 90s, the use of simplified technology was accompanied by the use of the following wheat varieties: "Zelinnya", "Yubilieynaya" and "Omskaya". During the 2000s, when agriculture made a transition to a resource-saving technology, still another group of wheat varieties was used: "Omskaya", "Astana", "Svetlanka" and "In Memory of Aziyev". Therefore, values of categorical binary variables that correspond to certain technologies and wheat varieties will match. This circumstance leads to the multicollinearity problem of factor variables in the model. The problem can be easily solved by eliminating a wheat variety variable from the model. However, in this case the numerical value of coefficient for factor variable on technologies will have its effect on the resulting characteristic of not only the technology itself but on the wheat varieties, too. As for the agricultural machinery, it should be noted that it is impossible to calculate separately the impact of technology and new machinery on the labour inputs rate in the production, since the development of these two components is intertwined and continually progressing. We should bear in mind the above mentioned circumstances while interpreting the results of the problem solution.

\subsection{Construction of Econometric Model to Examine the Impact of Technology on Wheat Productivity}

The relation between wheat productivity and production factors in this numerical research model includes these important variables:

1) Quantitical variables - precipitation from October to July and the temperature regime in June;

2) Categorical variables - growth technology (including used classes), which is included in the model as a binary 
variable and taking value 1 , if used, and 0 if not used in any of the analytical periods.

Formally this model looks like:

$$
Y=b_{0}+\sum b_{i} X_{i}+\sum b_{j} T_{j}
$$

Where $\mathrm{Y}$ - crop productivity, centners per hectar;

$X_{j}$ - quantitical variables depended on natural conditions and resource costs (precipitation and temperature regime)

$T_{j}$ - categorical variables (cultivation technologies used);

$b_{0}, b_{i}, b_{j}$ - parameters (coefficients) of the model.

The parameters $b_{i}$ with the quantitical variables $X_{i}$ show the value of wheat productivity change Y depending on the change of the value of corresponding factors per unit. The parameters $b_{j}$ with the variables $T_{j}$ confirm the change in wheat productivity level Y when using the corresponding wheat growth technology.

\section{Results}

Evaluation of parameters and calibration of the relationship model (1) under conditions of "Rodina" LLP, located in the Zelingradsky district of Akmolinskaya oblast (province), has been carried out on the basis of the specified production data for 1971-2012. Related data is given in table 2.

Table 2. Parameters of the relationship model between wheat productivity and production factors in Agrofirma "Rodina" LLP (basic technology—conservation tillage technology)

\begin{tabular}{lll}
\hline Item No. & Factors & Values of parameters \\
\hline 1 & Hydrothermal production conditions: & \\
1.1 & precipitation (October-July) & 0.03 \\
1.2 & Temperature (June) & -0.88 \\
2 & Production technology: & \\
2.1 & Intensive & 0.47 \\
2.2 & Simplified & 1.56 \\
2.3 & Minimized & 3.51 \\
3 & Free coefficient & 20.74 \\
\hline
\end{tabular}

The econometrical relationship model in numerical format looks like:

$\mathrm{Y}=20.74+0.47 * \mathrm{IT}+1.56 * \mathrm{ST}+3.51 * \mathrm{MT}+0.03 * \mathrm{P}-0.88 * \mathrm{~T}$,

Where IT - intensive technology,

ST - simplified technology,

MT - minimized technology,

$\mathrm{P}$ - precipitation,

$\mathrm{T}$ - temperature.

Multiple correlation coefficient is high enough (0.69); determination coefficient is 0.47 . The assessment of the relationship model according to Fisher's criteria shows that on the level of trust of 0.05 received equation is relevant and gives reliable enough results (estimated rate $\mathrm{F}_{\text {est. }}=8.28$ for $\mathrm{F}_{\text {table }}=2.42$ ).

Results of the relationship model calibration, presented in Table 2, suggest the following: the increase of the total amount of precipitation that fall from October to July by one millimetre from its average provides wheat productivity growth by $0.03 \mathrm{c} / \mathrm{ha}$; the increase of air temperature in June by one degree from its average leads to the crop productivity decrease by $0.88 \mathrm{c} / \mathrm{ha}$; the transition to intensive technology in the early $80 \mathrm{~s}$ led to the wheat productivity increase of $0.47 \mathrm{c} / \mathrm{ha}$ in comparison with conservation tillage technology; simplified technology provided wheat yield growth by $1.56 \mathrm{c} / \mathrm{ha}$ in comparison with conservation tillage technology; the 
substitution of conservation tillage technology with minimized technology increases wheat productivity by 3.51 $\mathrm{c} / \mathrm{ha}$. The influence of various factors on wheat productivity formation is shown in Table 3 .

Table 3. Change of wheat productivity level under the alteration of production conditions in "Rodina" LLP (1971-2012)

\begin{tabular}{|c|c|c|c|c|c|}
\hline \multirow[t]{2}{*}{$\begin{array}{l}\text { New/old } \\
\text { Technology }\end{array}$} & \multicolumn{3}{|c|}{$\begin{array}{l}\text { Wheat yield growth, c/ha, on account of change } \\
\text { of: }\end{array}$} & \multirow[t]{2}{*}{$\begin{array}{l}\text { Total } \\
\text { growth }\end{array}$} & \multirow{2}{*}{$\begin{array}{l}\text { Wheat productivity } \\
\text { under new/ old } \\
\text { conditions, c/ha }\end{array}$} \\
\hline & precipitation & Temperature & Technology & & \\
\hline Intensive/No till & 0.14 & -0.81 & 0.47 & -0.2 & $10.3 / 10.5$ \\
\hline Simplified/Intensive & 0.16 & 0.83 & 1.09 & 2.08 & $12.4 / 10.3$ \\
\hline Minimized/Simplified & 0.07 & -1.01 & 1.95 & 1.01 & $13.4 / 12.4$ \\
\hline
\end{tabular}

It follows from Table 3 that on account of average annual precipitation in the period of using intensive technology, wheat productivity increased by $0.14 \mathrm{c} / \mathrm{ha}$ in comparison with conservation tillage technology; productivity decreased because of less favourable temperature $(-0.81 \mathrm{c} / \mathrm{ha})$, which had been compensated by productivity growth because of the use of a more progressive technology $(0.47 \mathrm{c} / \mathrm{ha})$; and overall growth made up $0.2 \mathrm{c} / \mathrm{ha}$, which means that average productivity in the period of intensification decreased from $10.5 \mathrm{c} / \mathrm{ha}$ to $10.3 \mathrm{c} / \mathrm{ha}$ in comparison with the conservation tillage technology application period.

After the transition from intensive to simplified technology, average productivity increased by $0.16 \mathrm{c} /$ ha because of the large amount of precipitation during the simplified technology application period; productivity increased by $0.83 \mathrm{c} / \mathrm{ha}$ because of the favourable temperature regime in June, and the use of simplified technology increased productivity growth by $1.09 \mathrm{c} / \mathrm{ha}$; overall growth made up $2.08 \mathrm{c} / \mathrm{ha}$; and the average productivity during the simplified technology application period equalled to $12.4 \mathrm{c} / \mathrm{ha}$.

During the minimal technology application period, wheat productivity increased by $0.07 \mathrm{c} / \mathrm{ha}$ because of the high amount of precipitation; productivity decreased because of a less favourable temperature regime $(-1.01 \mathrm{c} / \mathrm{ha})$, and new technology caused growth in productivity by $1.95 \mathrm{c} /$ ha; overall growth made up $1.01 \mathrm{c} / \mathrm{ha}$. The average productivity during the minimized technology application period equalled to $13.4 \mathrm{c} / \mathrm{ha}$.

\section{Discussion}

The most significant factor affecting the wheat productivity in Kazakhstan appeared to be climatic conditions and amount of precipitation, in particular (Lioubimtseva \& Henebry, 2012.). Variables such as average monthly temperature, the total amount of monthly precipitation and average monthly precipitation throughout the three Kazakhstan cities, Astana, Kostanai and Petropavlovsk, were analyzed drawing on the available data during the period from 1951 to 2012 (Longmire \& Moldashev, 1999). The most striking and important correlation was identified between wheat productivity and the amount of precipitation accumulated from the beginning of the year to June $(\mathrm{r}=0.78)$. Average monthly temperature appeared to have the highest negative correlation in July $(\mathrm{r}=0.53)$ (Nagy \& Sanders, 1990; Morgounov et al., 2005). During the period of 1951-1990s, the lack of the necessary amount of precipitation caused the decrease of wheat productivity. The years 1996-2000 were favorable enough in terms of climatic conditions; however, economic conditions did not contribute much to a higher level of wheat productivity (Baydildina et al., 2000; Meng, 2000; Morgounov et al., 2007). For the past five years, deviation of wheat productivity level and precipitation amount from the average has reached its maximum. To some extent, this deviation gives the evidence of a considerable change in wheat growth technology and of a more vast use of moisture-resource-saving agricultural technology, as well as simplified and intensive technology (Alstone et al., 1995; Longmire and Moldashev, 1999; Morgounov et al., 2001).

These technologies have been implemented on a large scale for the past 10 years (Petrick et al., 2012). The studies that were carried out by the Kazakhstan researchers also show a higher level of wheat productivity while using the intensive wheat growth technology (Shegebaev, 1997; Babu \& Tashmatov, 2000; Morgounov et al., 2007). The Kazakhstan government supports the use of moisture-resource-saving technology by increasing the rate of subsidies (up to $100 \%$ of the basic rate) for one ha of harvested area. The Kazakhstan researchers argue that the government played an important role in the spread of moisture-resource-saving technology (Shegebaev, 1997; Longmire and Moldashev, 1999; Babu and Tashmatov, 2000; Morgounov et al., 2007). As such, the present efforts were definitely a new addition to the previous fund of knowledge. Thus, it should be concluded 
that in the period from 1971 to 2012, the implementation of new technologies caused a positive effect on wheat productivity growth.

\section{Acknowledgements}

Current studies were conducted at S. Seifullin Kazakh Agrotechnical University with the cooperation of L. N. Gumilyov Eurasian National University and Kazakh University of Technology and Business. The authors express their deep appreciation and thanks to the senior specialist of the International Cooperation Department Ms. Gulden Akhmejanova and academic writing consultant Dr. Robyn Ann Bantel from Gumilyov Eurasian National University for their assistance in translating the paper into English.

\section{References}

Alstone, J. M., Norton, G., \& Pardey, P. G. (1995). Science under Scarcity: Principles and Practice for Agricultural Research Evaluation and Priority Setting. Ithaca: Cornell University Press.

Ashfaq, M., Zulfiqar, F., Sarwar, I., Quddus, M. A., \& Baig, I. A. (2011). Impact of climate change on wheat productivity in mixed cropping system of Punjab. Soil and Environment, 30(2), 110-114.

Babu, S. C., \& Tashmatov, A. (2000). Food policy reforms in Central Asia: Setting the research priorities. Washington, DC.: International Food Policy Research Institute.

Baydildina, A., Akshinbay, A., Bayetova, M., Mkrytichyan, L., Haliepesova, A., \& Ataev, D. (2000). Agricultural policy reforms and food security in Kazakhstan and Turkmenistan. Food Policy, 25(6), 733-747. http://dx.doi.org/10.1016/S0306-9192(00)00035-X

De Beurs, K. M., \& Henebry, G. M. (2004). Land surface phenology, climatic variation, and institutional change: Analyzing agricultural land cover change in Kazakhstan. Remote Sensing of Environment, 89(4), 497-509. http://dx.doi.org/10.1016/j.rse.2003.11.006

FAO. (2012). Statistical database. Retrieved from http://www.fao.org

Griffith, G. R., Vere, D. T., \& Bootle, B. W. (1995). An integrated Approach to Assessing the Farm and Market Level Impacts of New Technology Adoption in Australian Lamb Production and Marketing Systems: The Case of Large, Lean Lamb. Agricultural Systems, 47, 175-198. http://dx.doi.org/10.1016/0308-521X(94)P4410-4

Knight, C. W., Wooding, F. J., \& Lewis, C. E. (1978). Relationships between temperature and wheat adaptation in Alaska. Agronomy Abstracts, 11.

Liefert, W., Liefert, O., Vocke, G., \& Allen, E. (2010). Former Soviet Union region to play larger role in meeting world wheat needs. Economic Research Service, US Department of Agriculture. Amber Waves.

Lioubimtseva, E., \& Henebry, G. M. (2012). Grain production trends in Russia, Ukraine and Kazakhstan: New opportunities in an increasingly unstable world? Frontiers of Earth Science, 6(2), 157-166. http://dx.doi.org/10.1007/s11707-012-0318-y

Longmire, J., \& Moldashev, A. (1999). Changing competitiveness of the wheat sector of Kazakhstan and sources of future productivity growth. CIMMYT Economics Paper 99-06. Mexico, D.F.

Meng, E., Longmire, J., \& Moldashev, A. (2000). Kazakhstan's wheat system: priorities, constraints, and future prospects. Food Policy, 6, 701-717. http://dx.doi.org/10.1016/S0306-9192(00)00038-5

Mizina, S. V., Smith, J. B., Gossen, E., Spiecker, K. F., \& Witkowski, S. L. (1999). An evaluation of adaptation options for climate change impacts on agriculture in Kazakhstan. Mitigation and Adaptation Strategies for Global Change, 4(1), 25-41. http://dx.doi.org/10.1023/A:1009626526883

Morgounov, A., Karabayev, M., Bedoshvili, D., \& Braun, H. J. (2001). Improving wheat production in Central Asia and the Caucasus. Research highlights of the CIMMYT Wheat Program, 1999-2000. Mexico, D.F.

Morgounov, A., Braun, H. J., Ketata, H., \& Paroda, R. (2005). International cooperation for winter wheat improvement in central Asia: Results and perspectives. Turk. J. Agric., 29, 137-142.

Morgounov, A., Gomez-Becerra, H. F., Abugalieva, A., Dzhunusova, M., Yessimbekova, M., Muminjanov, H., \& Cakmak, I. (2007). Iron and zinc grain density in common wheat grown in Central Asia. Euphytica, 155(1-2), 193-203. http://dx.doi.org/10.1007/s10681-006-9321-2

Morgounov, A., Rosseeva, L., \& Koyshibayev, M. (2007). Leaf rust of spring wheat in Northern Kazakhstan and Siberia: Incidence, virulence, and breeding for resistance. Crop and Pasture Science, 58(9), 847-853. http://dx.doi.org/10.1071/AR07086 
Nagy, J. G., \& Sanders, J. H. (1990). Agricultural technology development and dissemination within a farming systems perspective. Agricultural Systems, 32, 305-320. http://dx.doi.org/10.1016/0308-521X(90)90097-A

Petrick, M., Wandel, J., \& Karsten, K. (2012). Economic and social impacts of recent agro-investment in Kazakhstan's grain region. In Annual World Bank Conference on Land and Poverty. The World Bank, Washington DC.

Shegebaev, O. S. (1997). Scientific support for spring wheat production in Kazakhstan. In A. Morgounov, A. Satybaldin, S. Rajaram, \& A. McNab (Eds.), Spring Wheat in Kazakhstan: Current Status and Future Directions (pp. 24-30). Mexico, D.F.

Tarrant, J. R. (1984). Predicting USSR wheat production. Applied Geography, 4(1), 47-57. http://dx.doi.org/10.1016/0143-6228(84)90004-3

\section{Copyrights}

Copyright for this article is retained by the author(s), with first publication rights granted to the journal.

This is an open-access article distributed under the terms and conditions of the Creative Commons Attribution license (http://creativecommons.org/licenses/by/3.0/). 